\title{
Ventilator-associated pneumonia and oral health
}

\author{
Fernando Bellissimo-Rodrigues ${ }^{[1]}$ and Wanessa Teixeira Bellissimo-Rodrigues ${ }^{[2]}$
}

[1]. Departamento de Medicina Social, Faculdade de Medicina de Ribeirão Preto, Universidade de São Paulo, Ribeirão Preto, SP. [2]. Departamento de Clínica Médica, Divisão de Moléstias Infecciosas e Parasitárias, Faculdade de Medicina de Ribeirão Preto, Universidade de São Paulo, Ribeirão Preto, SP.

If it is true that intensive care saves many lives, it also involves risks to patients. Among those risks, ventilator-associated pneumonia (VAP) is one of the most frequent ones worldwide.

Taking into account the epidemiology of VAP among different Brazilian hospitals, it is of note that we systematically report a much higher incidence of VAP (17.8-24.6 episodes per 1,000 ventilator days $)^{1-3}$ than the incidence reported by the National Healthcare Safety Network (NHSN) of the Centers for Disease Control and Prevention (2.5-12.3 episodes per 1,000 ventilator days), which is based on the United States of America (USA) and is considered a global reference on the field of infection control ${ }^{4}$.

In fact, many reasons could be elicited to explain such differences and we bring the reader's attention to three of them that we believe may play a relevant role in that explanation.

First, it may be that we overestimate our incidence rates, because the VAP diagnosis is not that simple, there being many differential diagnoses, such as alveolar hemorrhage, pulmonary infarct, heart failure, atelectasis, acute respiratory distress syndrome, among others. So, in the intensive care unit (ICU), when a patient develops VAP suspicious, a chest computerized tomography scan may be required, and/or a bronchoscopy followed by microbiological cultures and/ or a pulmonary biopsy to define the diagnosis and determine the therapeutic approach. Those invasive techniques are not always available in the vast majority of Brazilian ICUs but are frequently used among North-American ICUs, maybe leading them to rule out those alternative diagnostics more properly ${ }^{5}$.

Second, although definite data is lacking, we believe that nurse understaffing is far more frequent among Brazilian ICUs than among North-American ICUs. While they discuss what is the most adequate patient/nurse ratio, 1:1 or 2:1, Brazilian federal regulation demands ICUs to have an 8:1 ratio, relaying most of the nursing care in the hands of nursing technicians. There is increasing evidence that nurse understaffing may be related to poor hand-hygiene compliance and a worse nursing care, eventually incrementing the risk of nosocomial infections, including VAP6.

But what we felt is the most relevant difference between South and North-American populations, regarding VAP susceptibility, is the oral health status. It is well known that the pathophysiology of VAP

\footnotetext{
Address to: Prof. Fernando Bellissimo-Rodrigues. Depto de Medicina Social da FMRP/USP. Av. Bandeirantes 3900, Monte Alegre, 14048-900 Ribeirão Preto, SP, Brasil.

e-mail: fbellissimo@fmrp.usp.br

Phone: 5516 3602-2714

Received in 17/09/2012

Accepted in 01/10/2012
}

begins in most cases with the migration of pathogenic bacteria from the oral cavity to the airways and the lungs. In this sense, a poor oral health is an established risk factor for nosocomial pneumonia, related or not to mechanical ventilation.

A recent national survey of the Brazilian population oral health status made by the Ministry of Health has shown that by the age of 12 years, $56.5 \%$ experienced at least one caries event and the mean Decayed/Missing/Filled/Teeth index (DMFT) at this age is 2.07, being 1.19 in the USA for the same age ${ }^{7,8}$. The mean DMFT index observed among adults in Brazil is 27.53 in the age range 65-74 years, which is also higher than the 22.4 index, observed among north-Americans aged 60 and above.

When it comes to periodontal disease, analyzed according to the Community Periodontal Index (CPI), the prevalence identified in Brazil, counting excluded sextants, is around $82.2 \%$ for persons aged $35-44$ years and $98.2 \%$ for persons aged $65-74$ years, while being only $47 \%$ for adults aged 30 years and above in the USA ${ }^{9}$.

We previously demonstrated that the topical application of chlorhexidine as an oral antiseptic is ineffective for VAP prevention, on the context of a poor oral health and hygiene ${ }^{10}$. Although chlorhexidine inactivates oral microbes efficiently in vitro, the great microbial concentration on teeth biofilms and periodontal pockets renders it ineffective in vivo.

Despite the progress observed in Brazil on the area of primary prevention of caries, related mainly to the implementation of routine water fluorination in the last decades, we made little progress in the efforts to offer public dental treatment, as it is needed.

The consequences of a poor oral health go far beyond the enhanced susceptibility to nosocomial infections and affect the nutritional status, cardiovascular system, and quality of life of the affected people.

We believe that it is now time to pass through this ancient scenario and to invest in oral health promotion, recognizing them as a public health priority, as predicted in the constitution of our public health system. Meanwhile, for those in charge of Brazilian ICUs, it may be advised that more than doctors, we need nurses, physiotherapists, and dental surgeons working on our intensive care patients, thus enhancing their chances of surviving VAP and getting discharged from the hospital alive.

\section{CONFLICT OF INTEREST}

The authors declare that there is no conflict of interest. 


\section{REFERENCES}

1. Salomão R, Rosenthal VD, Grimberg G, Nouer S, Blecher S, BuchnerFerreira $S$, et al. Device-associated infection rates in intensive care units of Brazilian hospitals: findings of the International Nosocomial Infection Control Consortium. Rev Panam Salud Publica 2008; 24:195-202.

2. Silva Júnior JM, Rezende E, Guimarães T, Campos EV, Magno LA, Consorti L, et al. Epidemiological and microbiological analysis of ventilator-associated pneumonia patients in a public teaching hospital. Braz J Infect Dis 2007; 11:482-488.

3. Porto JP, Mantese OC, Arantes A, Freitas C, Gontijo-Filho PP, Ribas RM. Nosocomial infections in a pediatric intensive care unit of a developing country: NHSN surveillance. Rev Soc Bras Med Trop 2012; 45:475-479.

4. Edwards JR, Peterson KD, Andrus ML, Tolson JS, Goulding JS, Dudeck MA, et al. National Healthcare Safety Network (NHSN) Report, data summary for 2006, issued June 2007. Am J Infect Control 2007; 35:290-301.

5. American Thoracic Society and Infectious Diseases Society of America (ATS/ IDSA). Guidelines for the management of adults with hospital-acquired, ventilator-associated, and healthcare-associated pneumonia. Am J Respir Crit Care Med 2005; 171:388-416.
6. Ministério da Saúde, Agência Nacional de Vigilância Sanitária. ResoluçãoRDC n ㄱ, de 24 de fevereiro de 2010. Diário Oficial da União no 37 de 25/02/10 - seção 1 - página 48. [Cited 2012 September 14] Available from: http://www.saude.mg.gov.br/atos_normativos/legislacao-sanitaria/ estabelecimentos-de-saude/uti/RDC-7_ANVISA\%20240210.pdf/.

7. Ministério da Saúde, Secretaria de Vigilância em Saúde, Departamento de Atenção Básica, Coordenação Geral de Saúde Bucal. Projeto Saúde Bucal Brasil 2010: Pesquisa Nacional de Saúde Bucal - Resultados Principais. [Cited 2012 September 14]. Available from: http://189.28.128.100/dab/ docs/geral/projeto_sb2010_relatorio_final.pdf.

8. World Health Organization. WHO Oral Health Country. Area Profile Programme. Chosen Region: The Americas - AMRO. [Cited 2012 September 14]. Available from: http://www.mah.se/CAPP/Country-Oral-HealthProfiles/AMRO/.

9. Eke PI, Dye BA, Wei L, Thornton-Evans GO, Genco RJ, Beck J, et al. Prevalence of Periodontitis in Adults in the United States: 2009 and 2010. J Dent Res 2012; 91:914-920.

10. Bellissimo-Rodrigues F, Bellissimo-Rodrigues WT, Viana JM, Teixeira GCA, Nicolini E, Auxiliadora-Martins M, et al. Effectiveness of Oral Rinse with Chlorhexidine in Preventing Nosocomial Respiratory Tract Infections among Intensive Care Unit Patients. Infect Control Hosp Epidemiol 2009; 30:952-958. 